\title{
CHANGES IN CLINICAL AND CYTOGENETIC FINDINGS OF INVASIVE PRENATAL DIAGNOSIS FROM 1989 TO 2011 IN ISTANBUL; IMPACT OF THE BIOCHEMICAL SCREENING TESTS AND FETAL ULTRASONOGRAPHY
}

\author{
ISTANBUL'DA 1989-2011 YILLARI ARASINDA INVAZIF PRENATAL TANININ KLINIK \\ VE SITOGENETIK BULGULARINDAKI DEĞIŞIKLIKLER; BIYOKIMYASAL TARAMA \\ TESTLERININ VE FETAL ULTRASONOGRAFININ ETKISI
}

\author{
Seher BAŞARAN ${ }^{1,2}$ (D), Birsen KARAMAN ${ }^{1-3}$ (D), Melike KIRGIZ² (D), ibrahim Halil KALELIOĞLU (D), Recep HAS ${ }^{4}$ (D), \\ Tahir DEHGAN² (D), Alkan YILDIRIM³ (D), Güven TOKSOY ${ }^{1}$ (D), Atıl YÜKSEL ${ }^{4}$ (D)
Istanbul University, Istanbul Faculty of Medicine, 'Department of Medical Genetics, ${ }^{4}$ Department of Obstetrics and Gynecology, Istanbul, Turkey
2PREMED, Center for Genetic Diagnosis, Şişli, Istanbul, Turkey
${ }^{3}$ Istanbul University, Child Health Institute, Pediatric Basic Sciences, Istanbul, Turkey

ORCID IDs of the authors: S.B. 0000-0001-8668-4746; B.K. 0000-0001-8640-0176; M.K. 0000-0003-1760-9958; H.I.K. 0000-0003-1349-2561; R.H. 0000-0002-1372-8506; T.D. 0000-0001-8101-4145; A.Y. 0000-0002-8570-4298; G.T. 0000-0002-8103-9980; A.Y. 0000-0002-6487-0860

\begin{abstract}
Cite this article as: Basaran S, Karaman B, Kirgiz M, Kalelioglu IH, Has R, Dehgan T, et al. Changes in clinical and cytogenetic findings of invasive prenatal diagnosis from 1989 to 2011 in Istanbul; Impact of the biochemical screening tests and fetal ultrasonography. J Ist Faculty Med 2020;83(4):315-24. doi: 10.26650/IUITFD.2020.0074
\end{abstract}

\section{ABSTRACT}

Objective: To determine the impact of maternal serum screening tests (MS-STs) and ultrasonography (US) on clinical and cytogenetic findings in invasive prenatal diagnosis (IPD)

Material and Method: Results of 23469 amniocentesis (AC) and 2492 chorionic villus sampling (CVS) obtained over 23 years were compared with regard to two periods; before and after year 2000.

Results: Cases with advanced maternal age (AMA) decreased, while MS-STs and fetal US increased in the timeline. The rate of chromosome aberration increased from $10.1 \%$ to $17.6 \%$ in CVS and from $3.2 \%$ to $4.3 \%$ in AC. The common aneuploidies summed up to $69.6 \%$ of anomalies $(n=385)$ in CVS and $65.1 \%$ of anomalies $(n=892)$ in AC. When known parental carriers were excluded, the rate of chromosomal rearrangements was $1.4 \%$ in CVS and $1 \%$ in AC. Discrepant cytogenetic results between CVS and $A C$ were observed in $1.7 \%$ of CVS. The rate of true/possible true mosaicism, false-positive confined placental mosaicism (CPM) and false-negative CPM was $1.02 \%, 0.57 \%$ and $0.49 \%$ in CVS, respectively.

Conclusion: MS-ST and US had a serious impact on the indications for invasive procedures and the rates of chromosome ab-

\section{ÖZET}

Amaç: Invazif prenatal tanıda (IPT) maternal serum tarama testlerinin (MS-TT) ve fetal ultrasonografinin (USG) klinik ve sitogenetik bulgular üzerine olan etkisini belirlemek.

Gereç ve Yöntem: 23 yıllık süreçte invazif girişimle elde edilen 23469 amniyosentez (AS) ve 2492 koryon villus aspirasyonu uygulama (KVA) sonuçları, 2000 yılı öncesi ve sonrası iki döneme ayrılarak karşılaştırıldı.

Bulgular: İleri anne yaşı (IAY) ile başvuran olgu sayısı azalırken, MS-TT ve fetal USG endikasyonu ile başvuran olguların sayısında artma gözlendi. Kromozom anomali oranı KVA'da \%10,1'den $\% 17,6^{\prime}$ ya ve $A S^{\prime}$ de $\% 3,2^{\prime}$ den \%4,3'e yükseldi. Yaygın anöploidiler, KVA'da anomalilerin \%69,6'sını ( $n=385)$ ve AS'de anomalilerin \%65,1'ini ( $n=892$ ) oluşturdu. Bilinen kromozom anomali taşıyıcıları hariç tutulduğunda, kromozomal yeniden düzenlemelerin oranı KVA'da \%1,4 ve AS'de \%1 idi. KVA'nun \%1,7'sinde KVA ve AS arasında uyumsuz sitogenetik sonuçlar gözlendi. KVA'da gerçek/olası gerçek mozaiklik, yalancı pozitif plasentayla sınırlı mozaisizm (PSM) ve yalancı negatif PSM oranı sırasıly \% $1,02, \% 0,57$ ve $\% 0,49$ bulundu.

Corresponding author/iletişim kurulacak yazar: basarans@istanbul.edu.tr

Submitted/Başvuru: 23.06.2020 • Revision Requested/Revizyon Talebi: 05.07.2020 •

Last Revision Received/Son Revizyon: 06.07.2020 • Accepted/Kabul: 11.07.2020 • Published Online/Online Yayın: 07.10.2020

(C)Telif Hakkı $2020 \mathrm{~J}$ Ist Faculty Med - Makale metnine jmed.istanbul.edu.tr web sayfasından ulaşılabilir.

(C) Copyright 2020 by J Ist Faculty Med - Available online at jmed.istanbul.edu.tr 
errations. The presented data will establish a baseline for better genetic counseling regarding IPD and noninvasive PD (NIPD) in different risk groups.

Keywords: Invasive prenatal diagnosis, maternal serum screening tests, fetal ultrasonography, chromosome aberrations

\section{INTRODUCTION}

The risk of trisomies increases with maternal age, decreases with advancing gestation (1-3). Although half of the trisomy 21 (T21) conceptuses survive to term, it is the most common chromosomal abnormality seen at birth and AMA as a screening parameter allowed us to diagnose about $1 / 4$ of the T21s. The developing of the MS-ST known as "triple test" (TT) by using the three biochemical markers (Alfa fetoprotein, free B-human Chorionic Gonadotropin, unconjugated estriol) in the 1980s increased the detection rate of T21 to $60-70 \%$ (4). Another improvement in the risk estimation was the US screening to search the non-structural anomalies entitled "soft markers" associated with fetal aneuploidies like increased nuchal translucency (NT), hypoplastic nasal bone, short femur length, etc. (5). First trimester-ST using NT thickness and two MS-biochemical markers (free B-hCG and pregnancy-associated plasma protein $A$ ), raised the detection rate to $~ 90 \%$ for T21 at a false positive rate of $5 \%$, which exceeded $95 \%$ incorporating nasal bone and other special ultrasound markers (6-8). Recent improvements in NIPD use MS-cell free DNA (cf-DNA) technique, which influences the management of the high-risk pregnancies today and in the near future $(9,10)$.

Since the cf-DNA takes its source from cytotrophoblasts, it is expected that the technique comprises the specification of the cytotrophoblasts. Therefore it is necessary to determine its efficiency and consequences (11). For this aim, we reevaluated our cytogenetic data obtained from
Sonuç: MS-TT ve USG'nin invazif girişim endikasyonları ve saptanan kromozom anomali oranları üzerinde ciddi etkilerinin olduğu görülmüştür. Elde edilen veriler, farklı risk gruplarında IPT ve noninvazif prenatal tarama ile ilgili daha doğru ve yararlı genetik danışmanlık için bir temel oluşturacaktır.

Anahtar Kelimeler: Invazif prenatal tanı, Maternal serum tarama testleri, fetal ultrasonografi, kromozom anomalileri

the largest CVS and AC series during the past 23 years from Turkey. Istanbul with more than 15.000 .000 inhabitants is the most populated city in Turkey and the number of deliveries exceeds 212,000 yearly (12). Although some western countries established national screening policies $(13,14)$, there is no nationally approved prenatal screening program in Turkey.

\section{MATERIAL AND METHOD}

During the 23 year study period, 25961 invasive procedures (2492 CVS and 23469 AC) were performed in two centers situated in Istanbul conducted by similar principles, one faculty hospital setting from 1989 on, which was the first established center for PD in Turkey and private one from 1996 on. The clinical and cytogenetic data were evaluated for two periods; from 1989 to 1999 and 20002011, retrospectively.

Risk factors determined by genetic counseling for IPD were classified as follows; (1) risk for monogenic disorders (MD), (2) no increased risk for chromosome aberrations (NIR) (maternal anxiety, etc.), (3) low risk (LR) includes cases with 1\% risk for fetal chromosome aberrations (child with chromosome aberration, IVF/ICSI pregnancies, etc.), (4) advanced maternal age (AMA), (5) increased risk in MS-STs (MS-ST), (6) pathological US findings (P-US), (7) parental balanced chromosomal rearrangements (PBCR). The number of invasive procedures in different indications according to the period and applied technique were shown in Table 1.

Table 1: The number of invasive procedures according to the referring indications and to the periods in CVS and AC series.

\begin{tabular}{|c|c|c|c|c|c|c|}
\hline \multirow{2}{*}{ Indications } & \multicolumn{3}{|c|}{ CVS series } & \multicolumn{3}{|c|}{$A C$ series } \\
\hline & $\begin{array}{c}\text { First period } \\
n=662\end{array}$ & $\begin{array}{c}\text { Second period } \\
n=1830\end{array}$ & $\sum n=2492$ & $\begin{array}{c}\text { First period } \\
n=7426\end{array}$ & $\begin{array}{c}\text { Second period } \\
n=16043\end{array}$ & $\sum n=23469$ \\
\hline MD & 352 & 626 & 978 & 86 & 106 & 192 \\
\hline NIR & 4 & 9 & 13 & 188 & 289 & 477 \\
\hline LR & 43 & 14 & 57 & 578 & 379 & 957 \\
\hline AMA & 88 & 140 & 228 & 4633 & 6518 & 11151 \\
\hline ST & 6 & 276 & 282 & 1343 & 4697 & 6040 \\
\hline P-US & 112 & 714 & 826 & 543 & 3915 & 4458 \\
\hline PBCR & 54 & 48 & 102 & 44 & 93 & 137 \\
\hline Confirmation & 3 & 3 & 6 & 11 & 46 & 57 \\
\hline
\end{tabular}


Mean maternal age in AMA indication was 39.84 in CVS (range 35-48) and 37,97 in AC (range 35-49) in the first period; 39 (range 35-47) in CVS and 38 (range 35-51) in $A C$ in the second period. The cut-off level of combined risk was 1:300 in ST indication and mean maternal age was 32 (range 20-45) in the second period of CVS; 31 (range 16-45) in the first and 33 (range 18-47) in the second period of the $A C$ for this indication group. Cases without increased risk by combined first trimester-ST, but increased NT measurement were evaluated under P-US. P-US group includes all minor or major, single or multiple anomalies detected in US. Cases with accompanying risk factors for chromosome aberrations of the MD group were placed into the related indications (109 AMA in CVS; 46 AMA and 5 P-US in AC) and remainders into the NIR indication in Tables 2a-2b and 3a-3b. Accompanying risk factors (AMA in 146 CVS and in 1333 AC; ST in 65 CVS and 109 AC) in P-US were considered only in Figures 1a$1 \mathrm{~b}$. When more than one indication was assigned $7.5 \%$ in CVS and $19.4 \%$ in AC in the first period and $25 \%$ in CVS and $35.4 \%$ in AC in the second period), these cases were included into the group with the highest relative risk for chromosome anomaly. The cases re-evaluated due to ambiguous or abnormal results referred from external laboratories were excluded (6 CVS and 57 AC cases) from the series.

CVS was performed by transabdominal route by using 18 or 20 Gauge needles. Transcervical technique was applied in 208 cases until 1998. AC was performed by using a 20 Gauge needle. Mean gestational age was $13.6 \pm 3$ (range 9-29) in CVS and 18 (range 11-36), \pm 1.8 in AC. Procedure-related abortion risk was given as $1-2 \%$ for CVS and as $0.5 \%$ in the genetic counseling.

Both direct preparation/short term incubation (DP) and in-situ long term cell culture (LTCC) techniques were performed concurrently on CV samples, when adequate material was obtained, otherwise only LTCC. LTCCs were set up in two or three TC-25 flasks. Routinely 20 Giemsa banded metaphases at 450-550 band level were evaluated. If necessary, other banding and fluorescence in situ hybridization (FISH) techniques were applied. When the same anomaly was found in at least three DP-metaphases or in two flasks of LTCC, it was recorded as "mosaic", if it was possible, fetal tissues were further investigated. Classical polymorphic variants were not included in the anomalies. Chi-square analyses were performed for statistical analysis.

Table 2a: The changes in the number and frequencies of the chromosome aberrations according to the referring indications from first to second periods of CVS series.

\begin{tabular}{|c|c|c|c|c|c|c|c|}
\hline \multirow{2}{*}{ CVS Series } & \multicolumn{3}{|c|}{ First period } & \multicolumn{3}{|c|}{ Second period } & \multirow{2}{*}{ total rate \% } \\
\hline & $\sum n$ & anomalies $\mathrm{n}$ & anomalies \% & $\sum n$ & anomalies $n$ & anomalies \% & \\
\hline NIR & 308 & 2 & 0.7 & 533 & 8 & 1.5 & 1.2 \\
\hline LR & 42 & 4 & 9.5 & 13 & 0 & 0 & 7.3 \\
\hline AMA & 112 & 4 & 3.6 & 223 & 11 & 4.9 & 4.5 \\
\hline ST & 6 & 1 & 16.7 & 276 & 52 & 18.8 & 18.8 \\
\hline P-US & 110 & 19 & 17.3 & 714 & 225 & 31.5 & 29.6 \\
\hline PBCR & 53 & 34 & 64.2 & 48 & 25 & 52.1 & 58.4 \\
\hline Total & 631 & 64 & 10.1 & 1822 & 321 & 17.6 & 15.7 \\
\hline
\end{tabular}

Table 2b: The changes in the number and frequencies of the chromosome aberrations according to the referring indications from first to second periods of AC series.

\begin{tabular}{lccccccc}
\hline \multirow{2}{*}{ AC Series } & \multicolumn{3}{c}{ First period } & \multicolumn{3}{c}{ Second period } \\
anomalies $\mathbf{n}$ & anomalies $\%$ & $\sum \mathbf{n}$ & anomalies $\mathbf{n}$ & anomalies \% & total rate \% \\
NIR & 267 & 1 & 0.4 & 358 & 5 & 1.4 & 1 \\
LR & 577 & 8 & 1.4 & 379 & 4 & 1.1 & 1.3 \\
AMA & 3891 & 93 & 2.4 & 6539 & 140 & 2.1 & 2.2 \\
ST & 2056 & 52 & 2.5 & 4693 & 136 & 2.9 & 2.8 \\
P-US & 536 & 55 & 10.3 & 3906 & 322 & 8.2 & 8.5 \\
PBCR & 43 & 26 & 60.5 & 93 & 50 & 53.8 & 55.9 \\
Total & 7370 & 235 & 3.2 & 15443 & 657 & 4.3 & 3.9 \\
\hline
\end{tabular}


Table 3a: The number and the rate of distinct chromosome aberrations detected in CVS series divided according to the referring indications.

\begin{tabular}{|c|c|c|c|c|c|c|c|c|c|c|c|c|c|}
\hline \multirow{2}{*}{\multicolumn{2}{|c|}{ Chromosome anomalies* }} & \multicolumn{2}{|c|}{ NIR } & \multicolumn{2}{|c|}{ LR } & \multicolumn{2}{|c|}{ AMA } & \multicolumn{2}{|c|}{ ST } & \multicolumn{2}{|c|}{ P-US } & \multicolumn{2}{|c|}{ PBCR } \\
\hline & & $\mathrm{n}$ & $\%$ & $\mathbf{n}$ & $\%$ & $n$ & $\%$ & $\mathrm{n}$ & $\%$ & $\mathrm{n}$ & $\%$ & $\mathrm{n}$ & $\%$ \\
\hline $45, X$ and variants & $\mathrm{n}=42$ & 1 & 2.4 & 0 & - & 1 & 2.4 & 4 & 9.5 & 36 & 85.7 & 0 & - \\
\hline PolysomyX/Y & $n=6$ & 2 & 33.3 & 0 & - & 2 & 33.3 & 0 & - & 2 & 33.3 & 0 & - \\
\hline Trisomy 21 & $n=132$ & 0 & - & 2 & 1.5 & 7 & 35.6 & 29 & 22 & 88 & 66.7 & $6^{a}$ & 4.5 \\
\hline Trisomy 18 & $n=61$ & 0 & - & 0 & - & 1 & 1.6 & 4 & 66.7 & 55 & 90.2 & $1^{\text {a }}$ & 1.6 \\
\hline Trisomy 13 & $n=27$ & 0 & - & 0 & - & 1 & 3.7 & 2 & 7.4 & 23 & 85.2 & 1 & 3.7 \\
\hline Uncommon trisomies & $n=20$ & 2 & 10 & 1 & 5 & 1 & 5 & 8 & 40 & 8 & 40 & 0 & - \\
\hline Poliploidies & $n=20$ & 0 & - & 0 & - & 0 & - & 2 & 10 & 17 & 85 & 1 & 5 \\
\hline Balanced structural & $n=51$ & 5 & 9.8 & 1 & 2 & 2 & 3.9 & 1 & 2 & 7 & 13.2 & 35 & 68.6 \\
\hline Unbalanced structural & $n=26$ & 0 & - & 0 & - & 0 & - & 3 & 11.5 & 8 & 30.8 & 15 & 57.7 \\
\hline Total & $\mathrm{n}=385$ & 10 & 2.6 & 4 & 1 & 15 & 3.9 & 53 & 13.8 & 244 & 63.4 & 59 & 15.3 \\
\hline
\end{tabular}

*including translocations and mosaics

${ }^{a}$ Trisomy was detected additional to parental inherited balanced reciprocal translocation

Table 3b: The number and the rate of distinct chromosome aberrations detected in $\mathrm{AC}$ series divided according to the referring indication.

\begin{tabular}{|c|c|c|c|c|c|c|c|c|c|c|c|c|c|}
\hline \multirow{2}{*}{\multicolumn{2}{|c|}{ Chromosome anomalies* }} & \multicolumn{2}{|c|}{ NIR } & \multicolumn{2}{|c|}{ LR } & \multicolumn{2}{|c|}{ AMA } & \multicolumn{2}{|c|}{ ST } & \multicolumn{2}{|c|}{ P-US } & \multicolumn{2}{|c|}{ PBCR } \\
\hline & & $\mathrm{n}$ & $\%$ & $\mathbf{n}$ & $\%$ & $n$ & $\%$ & $\mathrm{n}$ & $\%$ & $\mathrm{n}$ & $\%$ & $\mathrm{n}$ & $\%$ \\
\hline $45, X$ and variants & $n=58$ & 1 & 0.2 & 0 & - & $6^{b}$ & 0.3 & $18^{b}$ & 31 & 33 & 56.9 & 0 & - \\
\hline Polysomy X/Y & $n=68$ & 0 & - & 0 & - & 32 & 47.1 & 18 & 26.5 & 18 & 26.5 & 0 & - \\
\hline Trisomy 21 & $n=339$ & 0 & - & 5 & 1.5 & 82 & 24.2 & 78 & 23 & 173 & 51 & $1^{\mathrm{a}}$ & 0.3 \\
\hline Trisomy 18 & $n=87$ & 0 & - & 0 & - & $13^{a}$ & 14.9 & 7 & 8.1 & 66 & 75.9 & $1^{\mathrm{a}}$ & 1.2 \\
\hline Trisomy 13 & $n=23$ & 0 & - & 1 & 4.3 & 5 & 21.7 & 2 & 8.7 & 15 & 65.2 & 0 & - \\
\hline Uncommon trisomies & $n=20$ & 0 & - & 0 & - & 5 & 25 & 4 & 20 & 11 & 55 & 0 & - \\
\hline Polyploidies & $n=17$ & 0 & - & 0 & - & 1 & 5.9 & 1 & 5.9 & 15 & 88.2 & 0 & - \\
\hline Balanced structural & $n=218$ & 5 & 2.3 & 6 & 2.8 & 74 & 33.9 & 47 & 21.6 & 22 & 10.9 & 64 & 29.4 \\
\hline Unbalanced structural & $n=62$ & 0 & & 0 & - & 15 & 24.2 & 13 & 21 & 24 & 38.7 & 10 & 16.1 \\
\hline Total & $\mathrm{n}=892$ & 6 & 0.7 & 12 & 1.4 & 233 & 26.1 & 188 & 21.2 & 377 & 42.3 & 76 & 8.5 \\
\hline
\end{tabular}

*including translocations and mosaics

aTrisomy was detected additional to the parental inherited balanced reciprocal translocation

${ }^{b}$ mosaic $45, X / X$ structural anomalies

Informed consent was obtained from each patient.

\section{RESULTS}

The annual changes in the percentage of the main indications were figured out for 23 years (Figure 1a-1b) in CVS and $A C$ series. The cases with accompanying risk factors (AMA, ST) in P-US indication were shown independently in these figures to demonstrate the impact of US on AMA and ST groups.
Out of 2492 CVS, 2459 could be karyotyped (success rate 98.7\%) and of 23469 AC, 23395 (success rate 99.7\%). A total of 25854 karyotypes were evaluated in this study. The maternal cell contamination (MCC) caused misdiagnosis in two cases of the earliest 500 LTCC of CV samples (0.8\%).

A total of 1277 (385 in CVS and 892 in AC) chromosome aberrations were detected in this study. The overall rate of chromosome aberrations increased from $10.1 \%$ to $17.6 \%$ in CVS and from $3.2 \%$ to $4.3 \%$ in $A C$ ( $p<0.001$ in 


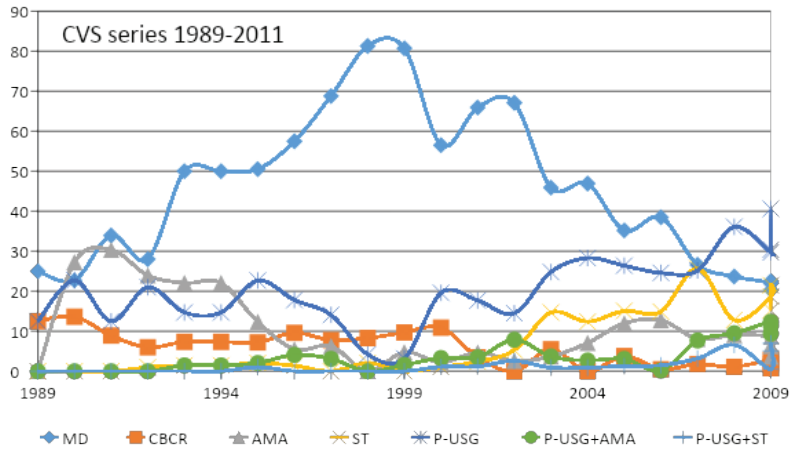

Figure 1a: Trends in CVS series during 23 years; annual proportion of the indications.

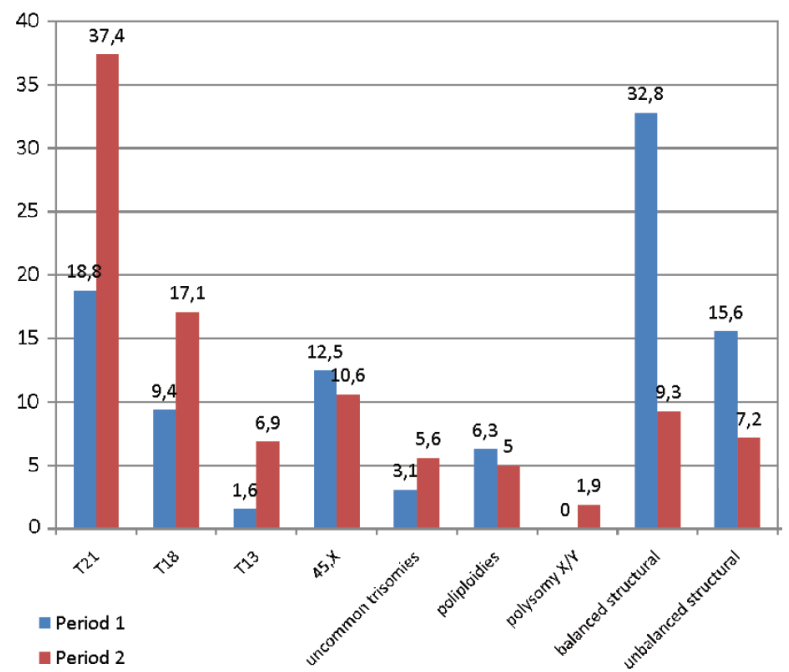

Figure 2a: The proportion of certain chromosome aberrations within the all aberrations compared between the periods of CVS series.

both series) from the first to the second period. This rate was higher in CVS versus AC in all indication groups. The highest abnormality rate except for the PBCR group was found in P-US, followed by ST and AMA in both series (Table 2a-2b).

When the proportion of certain aberrations within the all chromosome aberrations was compared between two periods, an increase of T21, T18, T13 and uncommon autosomal trisomies in CVS and of T21, T13 and 45, X in $A C$ was observed in the second period (Figures 2a-2b). Most frequently detected aneuploidies were T21 and T18 in both series, followed by $45, \mathrm{X}$ in CVS and by polysomy $X / Y$ in $A C$ (Figures 2a-2b).

Out of 51 balanced structural rearrangements detected in CVS series and of 218 detected in AC series, $68.6 \%$ and $29.4 \%$ of cases, respectively, were found in PBCR group

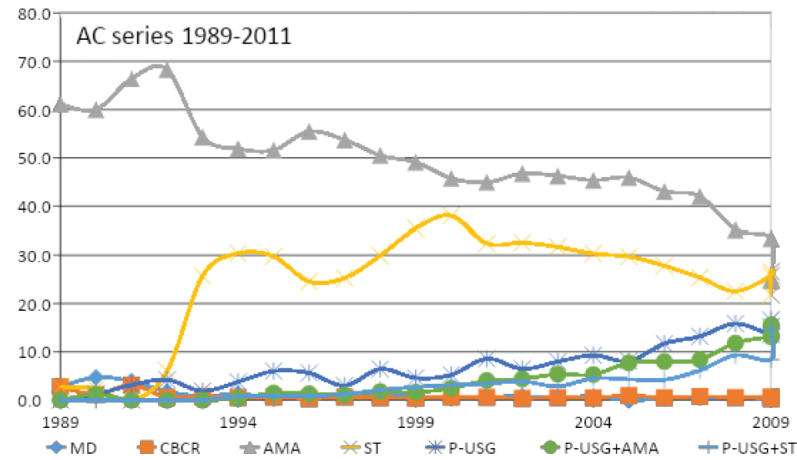

Figure 1b: Trends in AC series during 23 years; annual proportion of the indications.

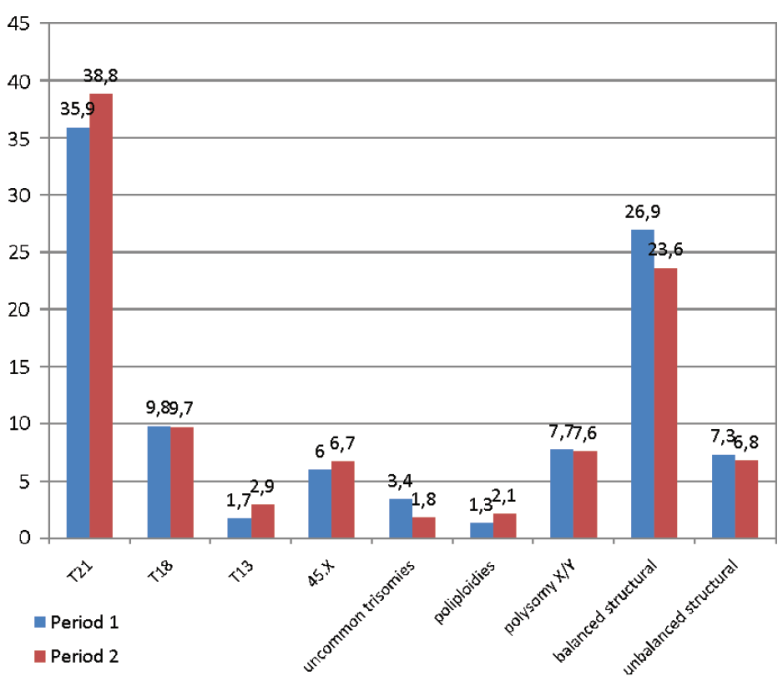

Figure 2b: The proportion of the certain chromosome aberrations within the all aberrations compared between the periods of $\mathrm{AC}$ series.

(Table 3a-3b). Out of 26 unbalanced rearrangements in CVS and of 62 in AC, $57.7 \%$ and $16.1 \%$ of cases was diagnosed in PBCR group (Table 3a-3b). The remaining chromosomal rearrangements diagnosed due to the indications rather than PBCR indication provided the identification of 138 new families with balanced chromosomal rearrangements. The mode of inheritance has remained unknown in ten cases and de novo occurrence has been shown in 18 cases of CVS $(0.7 \%)$ and 67 cases of $A C(0.3 \%)$, which were mostly unbalanced rearrangements $(15 / 18$ in CVS and 39/67 in AC). Except for the PBCR group, the frequency of the balanced rearrangements were $0.6 \%$ in CVS and $0.7 \%$ in $A C$ and of unbalanced rearrangements $0.5 \%$ in CVS and in $0.2 \% \mathrm{AC}$ (overall frequencies were $1.1 \%$ in CVS and $0.9 \%$ in $A C$ ).

Discrepant karyotypes between DP and LTCC of CVS and $A C$ were observed in 43 cases (1.7\%). Four cases were 
classified as "hidden true mosaicism" $(0.16 \%)$, because the both techniques of CVS revealed a nonmosaic trisomy (three T16 and one T13), but AF-LTCC karyotypes were normal. Further I-FISH investigation in AF cells indicated mosaicism in two cases. Mosaicism was observed in 39 CVS (1.59\%), of which 22 were "true mosaics" (0.9\%) and three were "possible true mosaics" (0.12\%). In 14 cases, DP revealed normal karyotype, while LTCC of CV a chromosome aberration, which were interpreted as "false negative DP-CPM" (0.57\%). Involved anomalies were 45,X, T9, T16, T21, structural rearrangements (each twice), polyploidy, T7, T8, T10 (each once). In one case, DP and LTCC showed discrepant findings (false negative and false positive DP concurrently) and in another case presented with pathological US, the anomaly observed in DP (T22) could not be found in LTCC, which was interpreted as CPM with false negative LTCC. Three of the false positive-CPMs were additional to the nonmosaic trisomies (two T18 and one T21).

US findings (at least one minor or major anomaly) were present in about $67 \%$ of $\mathrm{T} 21 \mathrm{~s}, 90 \%$ of $\mathrm{T} 18 \mathrm{~s}, 85 \%$ of $\mathrm{T} 13 \mathrm{~s}$, $86 \%$ of $45, X, 85 \%$ of polyploidies, $40 \%$ of uncommon trisomies in CVS, which were about 51\%, 76\%, 65\%, 57\%, 88\%, $55 \%$ in AC series, respectively (derived from Tables 3a-3b).

Common aneuploidies including mosaics (T21 and T13 including translocations, T18, 45,X and polysomy $\mathrm{X} / \mathrm{Y}$ )

Table 4a: The risk estimation for the common aneuploidies, for other unbalanced chromosomal aberrations associated with affected phenotype and for balanced rearrangements possibly associated with normal phenotype in CVS series in the main indications.

\begin{tabular}{|c|c|c|c|c|c|c|c|c|c|c|c|c|c|c|c|}
\hline \multirow{2}{*}{\multicolumn{2}{|c|}{$\begin{array}{l}\text { CVS } \\
\text { Indication }\end{array}$}} & \multirow{2}{*}{\multicolumn{2}{|c|}{$\begin{array}{c}\text { Total } \\
\text { chromosome } \\
\text { aberrations }\end{array}$}} & \multirow{2}{*}{\multicolumn{3}{|c|}{$\begin{array}{c}T 21,18,13,45, X \\
\text { and } X / Y \\
\text { polysomies }\end{array}$}} & \multicolumn{9}{|c|}{ Other chromosome aberrations } \\
\hline & & & & & & & \multicolumn{3}{|c|}{$\begin{array}{l}\text { Uncommon trisomies, } \\
\text { poliploidies, unbalanced } \\
\text { rearrangements }\end{array}$} & \multicolumn{3}{|c|}{$\begin{array}{l}\text { Balanced } \\
\text { rearrangements }\end{array}$} & \multicolumn{3}{|c|}{ Total risk } \\
\hline & $\sum \mathrm{n}$ & $\mathbf{n}$ & $\%$ & $\mathbf{n}$ & $\%$ & risk & $\mathrm{n}$ & $\%$ & risk & $\mathrm{n}$ & $\%$ & risk & $\sum \mathrm{n}$ & $\%$ & risk \\
\hline NIR & $n=841$ & 10 & 1.2 & 3 & 0.4 & $1: 250$ & 2 & 0.2 & 1:500 & 5 & 0.6 & $1: 167$ & 7 & 0.8 & $1: 125$ \\
\hline LR & $\mathrm{n}=55$ & 4 & 7.3 & 2 & 3.6 & $1: 28$ & 1 & 1.8 & $1: 56$ & 1 & 1.8 & $1: 56$ & 2 & 3.6 & $1: 28$ \\
\hline AMA & $n=335$ & 15 & 4.5 & 12 & 3.6 & $1: 28$ & 1 & 0.3 & 1:333 & 2 & 0.6 & 1:167 & 3 & 0.9 & 1:111 \\
\hline ST & $n=282$ & 53 & 18.8 & 39 & 13.8 & $1: 7$ & 13 & 4.6 & $1: 22$ & 1 & 0.4 & $1: 250$ & 14 & 5 & $1: 20$ \\
\hline P-US & $n=824$ & 244 & 29.6 & 204 & 24.8 & $1: 4$ & 33 & 4 & $1: 25$ & 7 & 0.9 & 1:111 & 40 & 4.9 & $1: 20$ \\
\hline PBCR & $n=101$ & 59 & 58.4 & 8 & 7.9 & $1: 13$ & 16 & 15.8 & $1: 6$ & 35 & 34.7 & $1: 3$ & 51 & 50.5 & $1: 2$ \\
\hline Total & $n=2453$ & 385 & 15.7 & 260 & 10.6 & & 50 & 2 & & 16 & 0.7 & & 66 & 2.7 & \\
\hline
\end{tabular}

Table 4b: The risk estimation for the common aneuploidies, for other unbalanced chromosomal aberrations associated with affected phenotype and for balanced rearrangements possibly associated with normal phenotype in AC series in the main indications

$\mathrm{AC}$

Indication
Total chromosome aberrations
$\mathrm{T} 21,18,13,45, \mathrm{X}$ and $X / Y$ polysomies

\section{Other chromosome aberrations}

\section{Uncommon trisomies, poliploidies, unbalanced rearrangements}

\section{Balanced rearrangements}

\section{Total risk}

\begin{tabular}{llcccccccccccccc} 
& $\sum \mathbf{n}$ & $\mathbf{n}$ & $\%$ & $\mathbf{n}$ & $\%$ & risk & $\mathbf{n}$ & $\%$ & risk & $\mathbf{n}$ & $\%$ & risk & 乏n & $\%$ & risk \\
NIR & $\mathrm{n}=25$ & 6 & 24 & 1 & 4 & $1: 25$ & - & - & - & 5 & 205 & $1: 5$ & 5 & 20 & $1: 5$ \\
LR & $\mathrm{n}=86$ & 12 & 14 & 6 & 7 & $1: 14$ & - & - & - & 6 & 7 & $1: 14$ & 6 & 7 & $1: 14$ \\
AMA & $\mathrm{n}=10430$ & 233 & 2.2 & 138 & 1.3 & $1: 77$ & 21 & 0.2 & $1: 500$ & 74 & 0.7 & $1: 143$ & 95 & 0.91 & $1: 111$ \\
ST & $\mathrm{n}=6749$ & 188 & 2.8 & 123 & 1.8 & $1: 56$ & 18 & 0.3 & $1: 368$ & 47 & 0.7 & $1: 143$ & 65 & 1 & $1: 100$ \\
P-US & $\mathrm{n}=4442$ & 377 & 8.5 & 305 & 6.9 & $1: 15$ & 50 & 1.1 & $1: 91$ & 22 & 0.5 & $1: 188$ & 72 & 1.6 & $1: 63$ \\
PBCR & $\mathrm{n}=136$ & 76 & 55.9 & 2 & 1.5 & $1: 67$ & 10 & 7.4 & $1: 14$ & 64 & 47.1 & $1: 2$ & 74 & 54.4 & $1: 2$ \\
Total & $\mathrm{n}=23813$ & 92 & 3.8 & 575 & 2.4 & & 117 & 0.5 & & 158 & 0.7 & & 293 & 1.2 & \\
\hline
\end{tabular}


summed up to $69.6 \%$ of all chromosome aberrations identified in CVS and $65.1 \%$ in AC series (derived from Figures 2a-2b). According to the indications, this percentage was about 30\% in NIR, 50\% in LR, $80 \%$ in AMA, 74\% in ST and 84\% in P-US in CVS, and 17\%, 50\%, 59\%, 65\% and $81 \%$ in AC, respectively (derived from Table 3a-3b). Remaining anomalies were grouped as; uncommon chromosome aberrations associated with abnormal phenotype and anomalies with possibly normal phenotype and the risks for these three groups of aberrations were calculated for the main indications (Table 4a-4b). The highest risk for common aneuploidies was in P-US (1:4 in CVS and 1:15 in AC) followed by ST and AMA indications in both series. The risk for uncommon chromosome aberrations associated with an abnormal phenotype, except PBCR indication was in ST indication of CVS (1:22) and in P-US (1:91) in AC series (Table 4a-4b).

\section{DISCUSSION}

\section{Trends in indications and invasive procedures}

The aim of the non-invasive STs is; 1 ) to assess more precisely risks of having a fetus with T21, T18 and T13, 2) to screen all pregnancies, including younger mothers, 3) to reduce the number of invasive procedures in normal pregnancies, 4) to diagnose more chromosome aberrations prenatally. Comprehensive studies from countries with well organized prenatal health care systems with national approved screening policies, demonstrated that the MS-ST and US screening changed the referral indications for IPD (14-16). All these reports pointed out to a clear decrease in AMA indication alone, but an increase in MS-ST and P-US indications and despite a decreased number of procedures, more chromosomal aberrations were diagnosed.

We retrospectively analyzed our data obtained from CVS and $A C$ series, and compared the results according to two periods (see Material and Methods) to determine the impact of the MS-STs and fetal US examination on the IPD, and on the frequency and the type of the chromosome aberrations. Although there is no national screening policy in Turkey, our results demonstrate the tremendous impact of MS-STs and US on our cohort. Our policy was to offer CVS as an alternative to women having a risk of $>5 \%$. Since the high-risk families, like those at risk for $\mathrm{MD}$ and $\mathrm{PBCR}$, were followed in our polyclinic and counseled about the facility of PD, they had the opportunity to choose CVS. The steady increase in the percentage of these indications in the 1990s could be explained by this policy. This percentage dropped back in the 2000s (Figure 1a), since relatively more CVS were performed due to the first trimester-ST and P-US indications. Parallel to the decrease of AMA, the increase of ST following the introduction of TT up until 1990 in AC (Figure 1b), and the introduction of first trimester-ST up until 2000 in CVS (Figure 1a) underlined the impact of STs on the families' decision on IPD. The increased percentage of cases having P-US findings (mostly soft markers) additional to AMA and/or ST indication demonstrated clearly the impact of US on IPD, even in PBCR indication (Figure $1 \mathrm{a}$ and $1 \mathrm{~b}$ ), since these families opted for AC in the 2000s especially, when US was normal. Pregnancies of the women with advanced age were monitored more closely and when first trimester-ST was positive, CVS; otherwise AC was a good choice for those women or IPD could be disapproved. Although ST became the most common indication for IPD in some countries, in our cohort, P-US in CVS and AMA in AC was the most common referral indication still in 2011 (14-16).

\section{Cytogenetic results}

As expected, the overall rate of chromosome aberrations in CVS was higher than in AC and also increased in the second period of both series (from $10.1 \%$ to $17.6 \%$ in CVS and from $3.2 \%$ to $4.3 \%$ in AC), which based on the facts that 1) first-trimester CVS can detect chromosome aberrations, which could not survive to the second-trimester of the pregnancy, 2) first-trimester US findings like cystic hygroma and other major malformations are closely related to severe/lethal chromosome aberrations, 3) the higher sensitivity of the first-trimester ST compared to $T T, 4)$ through the wide usage of STs and US, pregnancies having higher risk than the others are selected for IPD, 5) FISH for the detection of microdeletions could be applied in presence of specific US findings, 6) presence of CPM, 7) CVS was offered and preferred by PBCR group having the highest risk for chromosome aberration. It is well known that some of the unbalanced products of the parental rearrangements can not survive to the second trimester of pregnancy. The ratio of balanced to unbalanced products in PBCR indication in CVS (35:21) versus in AC (64:11) observed in our study supported this explanation.

The unexpected high rates (1.2\% in CVS and $1 \%$ in AC) of chromosome aberrations in the NIR group support the importance of fetal karyotyping in all prenatal samples, whatever the primary indication is for invasive procedure (Table 2a-2b). An interesting observation in the PBCR group was the high rate $(1.69 \%)$ of trisomies (twice T18 and each once T21 and T22) of younger mothers (except one T18) and of paternal translocations. Three reports described the increased prevalence of T21 and T18 children, whose parents were translocation carriers, which was explained by the term of "interchromosomal effect" (ICE) $(17,18)$. Schinzel et al. (1992) showed in seven T21 cases of translocation carriers (two mat and five pat), that all extra chromosomes were maternally inherited, which was against the former hypothesis (19). Some reports in sperm cells of translocation carriers indicated the high frequency of disomy, however more studies are needed to clarify the effect of ICE on aneuploidies $(20,21)$. 
Fetal US represents the most powerful and safe screening tool for chromosome aberrations. It is suggested that $>95 \%$ of all major chromosomal anomalies can be diagnosed in the first trimester of pregnancy, when US screening and MS-STs are applied in combination (8). Aneuploidy prevalence ranges from $1 \%$ to over $80 \%$ with different US anomalies (22). As expected, P-US indication has the highest detection rate for chromosome aberration, except PBCR indication, which varies between 6-20\% according to the selection criteria and used technique (overall frequency $29.6 \%$ in CVS and $8.5 \%$ in AC in this study). We observed that this frequency increased from the first to the second period (from 17.3\% to 31.5\%) in CVS, but slightly decreased in AC (from $10.3 \%$ to $8.2 \%$ ). This result could be explained by the advanced experiences in US and our clinical strategy. Advanced experiences in US allowed us to detect more specific abnormalities (NT, nasal bone, etc.) associated with certain trisomies in the first trimester and also to offer CVS, which caused a selection of pregnancies having higher risk than the others for CVS in our cohort. US was more effective in the diagnosis of T18, T13 and 45,X, than for T21 and it is important to note that US can be normal in about $1 / 3$ of the first and $1 / 2$ of the second trimester of the pregnancies with T21 (derived from Table 3a-3b), which should be shared in the genetic counseling.

Higher rate of chromosome aberration in ST indication of CVS than AC and in the second period of both series than in the first period (Table 2a-2b) shows clearly, that the first trimester-ST is more sensitive than TT for chromosome aberrations, since CVS was most frequently performed procedure in pregnancies with positive first trimester-ST. STs are focused on T21 lesser, T18 and T13, but it seems to be sensitive for uncommon trisomies, $45, \mathrm{X}$ and unbalanced rearrangements, too (Table 3a-3b).

The frequency of the chromosomal rearrangements increased from $0.26 \%$ to $0.58 \%$ by using a/the banding technique at a 400-500 band level. This frequency was $0.4 \%$ in the pioneer study and recent studies revealed a range between $0.53 \%-1.2 \%$ according to the patient selection criteria (including or excluding PBCR and P-US indication) $(3,23)$. The frequency of balanced rearrangements $(0.6 \%$ in $\mathrm{CVS} ; 0.7 \%$ in $\mathrm{AC})$ was in agreement with the literature $(0.35 \% ; 0.82 \%)$, while the frequency of unbalanced rearrangements in CVS (0.5\%) and in AC series $(0.2 \%)$ was higher compared to the prevalence in newborns $(0.2 \%)$ and previous prenatal reports $(0.18 \%-0.38 \%)$ (23-25). The overall frequency of chromosomal rearrangements excluding PBCR group $1.1 \%$ in CVS and $0.9 \%$ in $\mathrm{AC})$ and of de novo rearrangements in this study was also higher $(0.7 \%$ in CVS and $0.3 \%$ in AC) than of the pioneer study (3), which could be explained by the including of the microdeletions diagnosed by FISH applied in the presence of specific US findings, CPMs and the lack of parental karyotyping in cases with poor obstetric history and IVF/ICSI pregnancies prior to PD in our cohort. During this study, 138 new families carrier of chromosomal rearrangements were disclosed following the detection of fetal chromosomal rearrangements, which allowed us to counsel more precisely for ongoing pregnancies and also to guide for the management of future pregnancies and to determine the consequences of other family members.

$\mathrm{CV}$ tissue is still embracing the problems of MCC and mosaicism. MCC poses a greater risk in LTCC than in DP. Removal of the decidual tissue from the CV sample is essential to overcome the MCC problem. Until sufficient experience has been gained, exclusion of the MCC by using chromosomal fluorescence polymorphisms is recommended (26). Chromosomal mosaicism is seen in $1-2 \%$ of CV samples $(27,28)$. Only about $10 \%$ of these mosaics are found in the fetus (29). Approximately 16 to $21 \%$ of pregnancies with CPM involving T2, T7, T8, T9, T16 and T22, is associated with IUGR, fetal loss, poor perinatal outcome, which has been explained by placental malfunction due to the high percentage of abnormal cells, hidden fetal mosaicism or uniparental disomy (UPD) (30-33). When a mosaic chromosomal anomaly is found in CVS, detailed US should be performed; when US is uneventful, AC should be offered to avoid the false positive diagnosis, especially in T16, T13, T22 cases and further cytogenetic investigations in fetal tissues using different techniques are strongly recommended before the pregnancy is terminated (34). Due to the non-adequate follow up, false positive CVS results can lead to termination of the normal fetuses, however false negatives can cause the birth of an affected child. The previous reports indicated that the false negative results can be reduced to $0.03-0.08 \%$, when both DP and LTCC techniques are applied concurrently in CVS, otherwise it increases up to, when only DP is used (35). Our false negative findings $(0.49 \%)$ were also limited to the DP. I-FISH application in uncultured AF cells was very effective to enlighten the low level mosaics in cases with normal karyotypes according to our experience. There are case reports describing discordant results with false negative QF-PCR in common trisomies. In a large study with 22825 CVS, this discrepancy was $0.2 \%$ and explained by CPM (35). False negative and positive-CPM could be a serious potential source of error in NIPD using cf-DNA technique.

We reviewed our data, assuming that the hypothetical detection rate of cf-DNA test for common aneuploidies including mosaics $100 \%$, to determine the risk for anomalies rather than common aneuploidies, which is important in pre-counselling for NIPD versus IPD. This risk was 1:111 in both series in AMA indication. With respect to the phenotypic effect of these anomalies; the risk for anomalies associated with abnormal phenotype was higher (1:333) in CVS than AC (1:500) (Table 5a-5b). 
We agree with Collins and Impey emphasizing that "All screening and diagnostic methods have their own specific risks and benefits. It is vital that adequate time and importance is given to exploring the parents' understanding and expectations before any test is embarked on, no matter how 'safe' it is perceived to be" (36).

Our study, based on the results of the largest CVS and AC series in Turkey, shows how STs and US strongly influenced the clinical and cytogenetic results in IPD (37-39). We believe that abnormality rates detected in different indication groups in this study could be considered as the baseline risks in genetic counseling for certain indications in NIPD.

Acknowledgments: The authors are grateful to the cytogenetic team, who are working for more than 20 years together. The authors thank Prof. Dr. Peter Miny for critical scientific input on the manuscript.

Ethics Committee Approval: Ethics committee approval was not received due to the retrospective nature of the study.

Informed Consent: Written consent was obtained from the participants.

Peer Review: Externally peer-reviewed.

Author Contributions: Conception/Design of Study- S.B., B.K., M.K., I.H.K., R.H., T.D., A.Y., G.T., A.Y.; Data Acquisition- S.B., B.K., M.K., I.H.K., R.H., T.D., A.Y., G.T., A.Y.; Data Analysis/Interpretation- S.B., B.K., M.K., I.H.K., R.H., T.D., A.Y., G.T., A.Y.; Drafting Manuscript- S.B., B.K., M.K., i.H.K., R.H., T.D., A.Y., G.T., A.Y.; Critical Revision of Manuscript- S.B., B.K., M.K., I.H.K., R.H., T.D., A.Y., G.T., A.Y.; Final Approval and Accountability- S.B., B.K., M.K., I.H.K., R.H., T.D., A.Y., G.T., A.Y.; Technical or Material Support- S.B., B.K., M.K., I.H.K., R.H., T.D., A.Y., G.T., A.Y.; Supervision- S.B., B.K., M.K., I.H.K., R.H., T.D., A.Y., G.T., A.Y

Conflict of Interest: Authors declared no conflict of interest.

Financial Disclosure: Authors declared no financial support.

Teşekkür: Prof. Dr. Peter Miny'e makaleye bilimsel katkılarından dolayı ve 20 yıldan daha uzun bir süredir birlikte çalıştığımız sitogenetik ekibine teşekkür ederiz.

Etik Komite Onayı: Retrospektif çalışma olduğundan etik komite onayı alınmamıştır.

Bilgilendirilmiş Onam: Katılımcılardan bilgilendirilmiş onam alınmıştır.

Hakem Değerlendirmesi: Dış bağımsız.

Yazar Katkıları: Çalışma Konsepti/Tasarım-S.B., B.K., M.K., i.H.K., R.H., T.D., A.Y., G.T., A.Y.; Veri Toplama- S.B., B.K., M.K., i.H.K., R.H., T.D., A.Y., G.T., A.Y.; Veri Analizi/Yorumlama- S.B., B.K., M.K., I.H.K., R.H., T.D., A.Y., G.T., A.Y.; Yazı Taslağı- S.B., B.K., M.K., i.H.K., R.H., T.D., A.Y., G.T., A.Y.; İçeriğin Eleştirel İncelemesi- S.B., B.K., M.K., I.H.K., R.H., T.D., A.Y., G.T., A.Y.; Son
Onay ve Sorumluluk- S.B., B.K., M.K., I.H.K., R.H., T.D., A.Y., G.T., A.Y.; Malzeme ve Teknik Destek- S.B., B.K., M.K., I.H.K., R.H., T.D., A.Y., G.T., A.Y.; Süpervizyon- S.B., B.K., M.K., I.H.K., R.H., T.D., A.Y., G.T., A.Y

Çıkar Çatışması: Yazarlar çıkar çatışması beyan etmemişlerdir.

Finansal Destek: Yazarlar finansal destek beyan etmemişlerdir.

\section{REFERENCES}

1. Adams MM, Erickson JD, Layde PM, Oakley GP. Down syndrome. Recent trends in the United States. JAMA 1981;246(7):758-760. [CrossRef]

2. Hook EB, Cross PK, Regal RR. The frequency of 47.+21, $47 .+18$, and $47,+13$ at the uppermost extremes of maternal ages: results on 56,094 fetuses studied prenatally and comparisons with data on livebirths. Hum Genet 1984;28(3):211-20. [CrossRef]

3. Ferguson-Smith MA, Yates JRW. Maternal age specific rates for chromosomal aberrations factors influencing them: report of a collaborative European study on 52,965 amniocenteses. Prenat Diagn 1984;4(7):5-44. [CrossRef]

4. Cuckle HS, Wald NJ, Thompson SG. Estimating a woman's risk of having a pregnancy associated with Down's syndrome using her age and serum alpha-fetoprotein level. Br J Obstet Gynaecol 1987;94(5):387-402. [CrossRef]

5. Snijders RJM, Nicolaides KH. Sequential screening. In: Nicolaides $\mathrm{KH}$, editor. Ultrasound markers for fetal chromosomal defects. Carnforth, UK: Parthenon; 1996.

6. Wald NJ, Hackshaw AK. Combining ultrasound and biochemistry in first-trimester screening for Down's syndrome. Prenat Diagn 1997;17(9):821-9. [CrossRef]

7. Spencer K, Macri JN, Aitken DA, Connor JM. Free beta hCG as first trimester marker for fetal trisomy. Lancet 1992;339(8807):1480. [CrossRef]

8. Nicolaides KH. Nuchal translucency and other first-trimester sonographic markers of chromosomal abnormalities. Am J Obstet Gynecol 2004;191(1):45-67. [CrossRef]

9. Lo DYM, Corbetta N, Chamberlain P, Rai V, Sargent IL, Redman CWG, Wainscoat JS. Presence of fetal DNA in maternal plasma and serum. Lancet 1997;350(9076):485-7. [CrossRef]

10. Wright CF, Chitty LS. Cell-free fetal DNA and RNA in maternal blood: implications for safer antenatal testing. BMJ 2009;339:b2451. [CrossRef]

11. Benn $\mathrm{P}, \mathrm{Cuckle} \mathrm{H}$ and Pergament E. Non-invasive prenatal diagnosis for Down syndrome: the paradigm will shift, but slowly. Ultrasound Obstet Gynecol2012;39(2):127-30. [CrossRef]

12. TUIK. www.turkstat.gov.tr Republic of Turkey Statistical Institute. Number:1325783/2015, Documents number: 7330775/7339623, Chapter 4.1, page 14.

13. Ekelund CK, Jørgensen FS, Petersen OB, et al. Danish Fetal Medicine Research Group. Impact of a new national screening policy for Down's sy ndrome in Denmark: population based cohort study. BMJ 2008;337:a2547. [CrossRef]

14. Lichtenbelt KD, Alizadeh BZ, Scheffer PG, et al. Trends in the utilization of invasive prenatal diagnosis in The Netherlands during 2000-2009. Prenat Diagn 2011;31(8):765-72. [CrossRef] 
15. Mademont-Soler I, Morales C, Clusellas N, et al. Prenatal cytogenetic diagnosis in Spain: analysis and evaluation of the results obtained from amniotic fluid samples during the last decade. Eur J Obstet Gynecol Reprod Biol 2011;157(2):156-60. [CrossRef]

16. Morris JK, Waters JJ, de Souza E. The population impact of screening for Down syndrome: audit of 19326 invasive diagnostic tests in England and Wales in 2008. Prenat Diagn 2012;32(6):596-601. [CrossRef]

17. Lindenbaum RH, Hulten M, McDermott $A$, Seabright $M$. The prevalence of translocations in parents of children with regular trisomy 21: A possible interchromosomal effect? J Med Genet 1985;22(1):24-8. [CrossRef]

18. Couzin DA, Watt JL, Stephen GS. Structural rearrangements in the parents of children with primary trisomy 21. J Med Genet 1987;24(5):280-2. [CrossRef]

19. Schinzel AA, Adelsberger PA, Binkert $F$, et al. No evidence for a paternal interchromosomal effect from analysis of the origin of nondisjunction in Down syndrome patients with concomitant familial chromosome rearrangements. Am J Hum Genet 1992;50(2):288-93.

20. Estop AM, Cieply K, Munne $S$, et al. Is there an interchromosomal effect in reciprocal translocation carriers? Sperm FISH studies. Hum Genet 2000;106(5):51724. Erratum in: Hum Genet 2000;107(1):95. [CrossRef]

21. Anton E, Vidal F, Blanco J. Interchromosomal effect analyses by sperm FISH: incidence and distribution among reorganization carriers. Syst Biol Reprod Med 2011;57(6):268-78. [CrossRef]

22. Daniel A, Athayde N, Ogle R, George AM, et al. Prospective ranking of the sonographic markers for aneuploidy: Data of 2143 prenatal cytogenetic diagnoses referred for abnormalities on ultrasound. Aust N Z J Obstet Gynaecol 2003;43(1):16-26. [CrossRef]

23. Forabosco A, Percesepe A, Santucci S. Incidence of nonage-dependent chromosomal abnormalities: a populationbased study on 88965 amniocenteses. Eur J Hum Genet 2009;17(7):897-903. [CrossRef]

24. Han SH, An JW, Jeong GY, Yoon HR, et al. Clinical and cytogenetic findings on 31,615 mid-trimester amniocenteses. Korean J Lab Med 2008;28(5):378-85. [CrossRef]

25. Jacobs PA, Browne C, Gregson N, Joyce C, White H. Estimates of the frequency of chromosome abnormalities detectable in unselected newborns using moderate levels of banding. J Med Genet 1992;29(2):103-8. [CrossRef]

26. Miny P, Holzgreve W, Başaran S, et al. Maternal cell contamination in chorionic villi cultures - exclusion by chromosomal fluorescence polymorphisms. Clin Genet 1985;28(3):262-3. [CrossRef]
27. Simoni G, Gimelli G, Cuoco C, et al. Discordance between prenatal cytogenetic diagnosis after chorionic vilus sampling and chromosomal constitution of the fetus. In: First trimester fetal diagnosis, Fraccaro M, Simoni G, Brambati B (ed.). Berlin: Springer Verlag. 1985;137. [CrossRef]

28. Hahnemann JM, Vejerslev LO. Accuracy of cytogenetic findings on chorion villus sampling (CVS)-Diagnostic consequences of CVS mosaicism and non-mosaic discrepancy in centres contributing to EUCROMIC 19861992. Prenat Diagn 1997;17(9):801-20. [CrossRef]

29. Phillips OP, Tharapel AT, Lerner JL, et al. Risk of fetal mosaicism when placental mosaicism is diagnosed by chorionic villus sampling. Am J Obstet Gynecol 1996;174(3):850-5. [CrossRef]

30. Johnson J, Wapner RJ, Davies GH, et al. Mosaicism in chorionic villus sampling: an association with poor perinatal outcome. Gynecology 1990;75(4):573.

31. Breed ASPM, Mantingh A, Vosters R, et al. Follow-up and pregnancy outcome after a diagnosis of mosaicism in CVS. Prenat Diagn 1991;11(8):577. [CrossRef]

32. Kalousek DK, Howard-Peebles PN, Olson SB, et al. Confirmation of CVS mosaicism in term placentae and high frequency of intrauterine growth retardation association with confined placental mosaicism. Prenat Diagn 1991;11(10):743-50. [CrossRef]

33. Wolstenholme J, Rooney DE, Davison EV. Confined placental mosaicism, IUGR, and adverse pregnancy outcome: a controlled retrospective UK collaborative survey. Prenat Diagn 1994;14(5):345-61. [CrossRef]

34. Miny P, Başaran S, Holzgreve W, Horst J, et al. False negative cytogenetic results in direct preparation after CVS. Prenat Diagn 1988;8(8):633. [CrossRef]

35. Holgado E, Liddle S, Ballard T, Levett L. Incidence of placental mosaicism leading to discrepant results between QF-PCR and karyotyping in 22,825 chorionic villus samples. Prenat Diagn 2011;31(11):1029-38. [CrossRef]

36. Collins SL, Impey L. Prenatal diagnosis: Types and techniques. Early Hum Dev 2012;88(1):3-8. [CrossRef]

37. Karaoguz MY, Bal F, Yakut T, Ercelen NO, Ergun MA, et al. Cytogenetic results of amniocentesis materials: incidence of abnormal karyotypes in the Turkish collaborative study. Genet Couns 2006;17(2):219-230.

38. Gunduz C, Cogulu O, Cankaya T, Bora E, et al. Trends in cytogenetic prenatal diagnosis in a reference hospital in Izmir/Turkey: a comparative study for four years. Genet Couns 2004;15(1):53-9.

39. Ilgin-Ruhi H, Yürür-Kutlay N, Tükün A, Bökesoy I. The role of genetic counseling on decisions of pregnant women aged 35 years or over regarding amniocentesis in Turkey. Eur $\mathrm{J}$ Med Genet 2005;48(1):13-19. [CrossRef] 